\title{
Demodex folliculorum on the eyelash follicule of diabetic patients
}

\author{
Demodex folliculorum nos cílios de pacientes diabéticos
}

Letícia Satsiê Fátima de Freitas Yamashita ${ }^{1}$, Angelino Julio Cariello², Nahin Mohamed Ali Geha², Maria Cecilia Zorat Yu³, Ana Luisa Hofling-Lima4

\begin{abstract}
Purpose: To compare the prevalence of Demodex folliculorum on the eyelashes of patients with proliferative diabetic retinopathy and healthy voluntaries.

Methods: Type 2 diabetic patients with proliferative retinopathy and age- and gender-matched healthy voluntaries (group control) underwent a slit lamp examination which three eyelashes containing cylindrical dandruff were removed from each lid by fine forceps. The lashes were dyed with fluorescein and the presence of Demodex folliculorum was verified by direct visualization under a light microscope. The mites were recognized based on its morphology and peculiar movement. The results were expressed in "positive" when at least one mite on one lash was found and "negative" when no mite was identified. The Chi-square test was used for comparing mites' presence in both groups.
\end{abstract}

Results: Forty-two patients were included in each group. The age ranged from 50 to 60 years old, with a mean of $56.4 \pm 5.2$ years. The male:female ratio was 0.6:1. There was no statistically significant difference with regard to age and gender in both groups ( $p>0.05)$. Demodex folliculorum was significantly more prevalent in diabetic patients (54.8\%) than in control patients (38.1\%) $(p=0.048)$.

Conclusion: Demodex folliculorum was more prevalent in diabetic patients than in healthy voluntaries, independently of gender and age.

Keywords: Blepharitis; Diabetes mellitus; Folliculitis; Eyelid diseases; Mites; Mite infestation

\section{RESUMO}

Objetivo: Comparara prevalência de Demodexfolliculorum nos cílios de pacientes com retinopatia diabética proliferativa e voluntários normais.

Métodos: Pacientes com diabetes mellitus tipo 2 apresentando retinopatia proliferativa e voluntários normais com mesma distribuição de sexo e idade (grupo controle) foram submetidos a exame em lâmpada de fenda. Três cílios com secreção "em colarete" foram removidos de cada pálpebra com pinça delicada. Os cilios foram corados com fluoresceína e a presença de Demodex folliculorum foi verificada por visualização direta através de microscópio de luz. As larvas foram reconhecidas baseadas em sua morfologia e movimentos peculiares. Os resultados foram expressosem "positivo"quando foiencontradapelo menos uma larva em um cílio e "negativo" quando nenhuma larva foi encontrada. O teste de Chi quadrado foi utilizado para comparar a presença das larvas nos dois grupos.

Resultados: Quarentae dois pacientes foram incluídos em cada grupo. Aidadevariou de 50 a 60 anos com média de 56,4 5,2 anos. A relação masculino:feminino foi de 0,6:1. Não houve diferença estatisticamente significante com relação ao sexo e idade entre os dois grupos $(p>0,05)$. Demodex folliculorum foi significantemente mais prevalente em pacientes com diabetes $(54,8 \%)$ que no grupo controle $(38,1 \%)(p=0,048)$.

Conclusão: Demodex foliculorum foi mais prevalente em pacientes diabéticos queem voluntários normais, independentemente do sexo e da idade.

Descritores: Blefarite; Diabetes mellitus; Foliculte; Doenças palpebrais; Ácaros; Infestaçôes por ácaros

\section{INTRODUCTION}

The Demodex sp. is a microscopic elongated mite considered the most common permanent ectoparasite of humans ${ }^{(1)}$. It has been observed in almost all age, racial and geographical groups ${ }^{(2)}$. Demodex feed on sebum and inhabit skin areas with active sebaceous excretion such as cheeks, forehead and nose ${ }^{(3)}$ and has been implicated in several skin diseases, for instance, acne vulgaris, rosacea, basal cell carcinoma and pityriasis folliculorum ${ }^{(4,5)}$.

In the eyelid, Demodex folliculorum can be found in the eyelash follicle and has been suggested as the etiologic agent of blepharitis. Indeed, several studies have demonstrated higher prevalence of Demodex on the eyelid of symptomatic patients with blepharitis compared to a control group ${ }^{(6,7)}$. However, since these mites are frequently found in healthy subjects, their pathogenicity remains controversial ${ }^{(8)}$.

Demodex infestation was also associated with immunodeficiency and various reports have been described this organism in biopsy sample obtained from skin inflammatory conditions in immunosuppressed patients with HIV infection ${ }^{(9)}$ or cancer $^{(10)}$. In addition, some studies have found higher mite density on the skin surface of po- tential immunosuppressed subjects, such as hemodialysis(11) and diabetic patients(3)

The aim of the present study was to compare the prevalence of Demodex folliculorum on the eyelashes of patients with proliferative diabetic retinopathy and on a normal control group.

\section{METHODS}

This study was approved by the institutional research ethics committee and written informed consents were obtained from all participants. This research is in compliance with the tenets of the Declaration of Helsinki.

Type 2 diabetic patients in laser treatment for proliferative retinopathy and age- and gender-matched healthy voluntaries (group control) were invited to participate. Exclusion criteria included pregnancy, diagnosis of diabetes under five years, prior eyelid surgery, known cause of immunosuppression (e.g. HIV infection, hemodialysis), current treatment for blepharitis and concomitant ocular or systemic disease that could interfere with the results of the study.

${ }^{4}$ Professor, Universidade Federal de São Paulo - UNIFESP - São Paulo (SP), Brazil.

Funding: No specific financial support was available for this study.

Disclosure of potential conflicts of interest: L.S.F.F.Yamashita, None; A.J.Cariello, None; N.M.A. Geha, None; M.C.Z.Yu, None; A.L.Höfling-Lima, None.

Correspondence address: Angelino Julio Cariello. Sadalla Amin Ghanem Eye Hospital. Rua Abdon Batista, 146 - Joinville (SC) - 89201-010 - Brazil - E-mail: angelino65@yahoo.com 
All subjects underwent a slit lamp examination at a magnification of X25 where three eyelashes containing cylindrical dandruff (Figure 1) were removed from each lid by fine forceps (one eyelash from each third of the eyelid) and placed separately on a glass slide. One drop of fluorescein solution was added and covered with a coverslip. Subsequently, the presence of Demodex was analyzed in the samples under a light microscope at a magnification of X40 and X100 (Figure 2). The examination was always performed by the same ophthalmologist (AJC) immediately after the sampling. The mites were recognized based on its morphology and peculiar movement. The results were expressed in positive (with a least one mite on one lash) and negative (no mite identifiable) and the Chi-square test was used for comparing mites presence in both groups.

\section{RESULTS}

Forty-two patients were included in each group. The age ranged from 50 to 60 years old, with a mean of $56.4 \pm 5.2$ years. The male:female ratio was $0.6: 1$. There was no statistically significant difference with regard to age and gender in both groups ( $p>0.05$ ).

Demodex folliculorum was significantly more prevalent in diabetic patients (27.4\% of the total population studied) than in control patients (19.0\% of the total population studied) as shown in the table 1

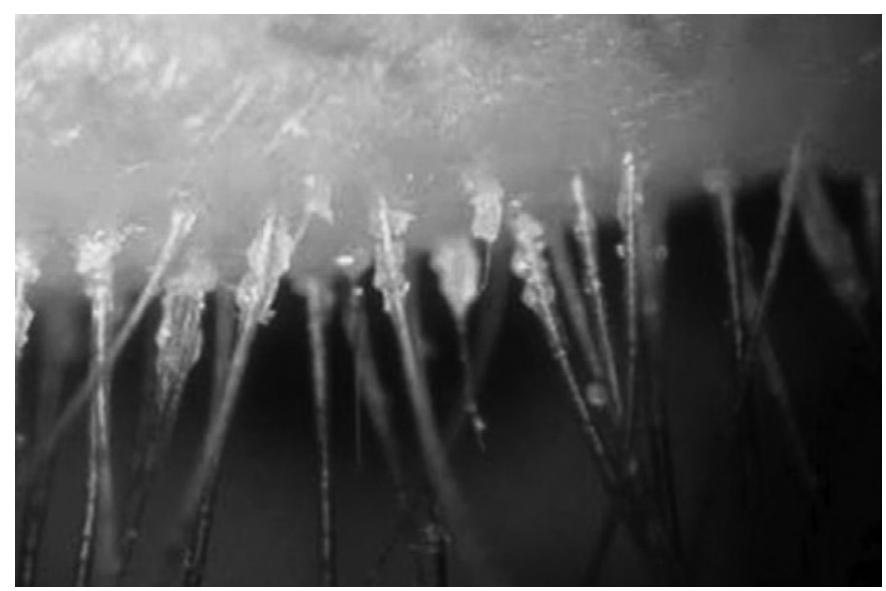

Figure 1. Eyelashes containing cylindrical dandruff under slit lamp examination.

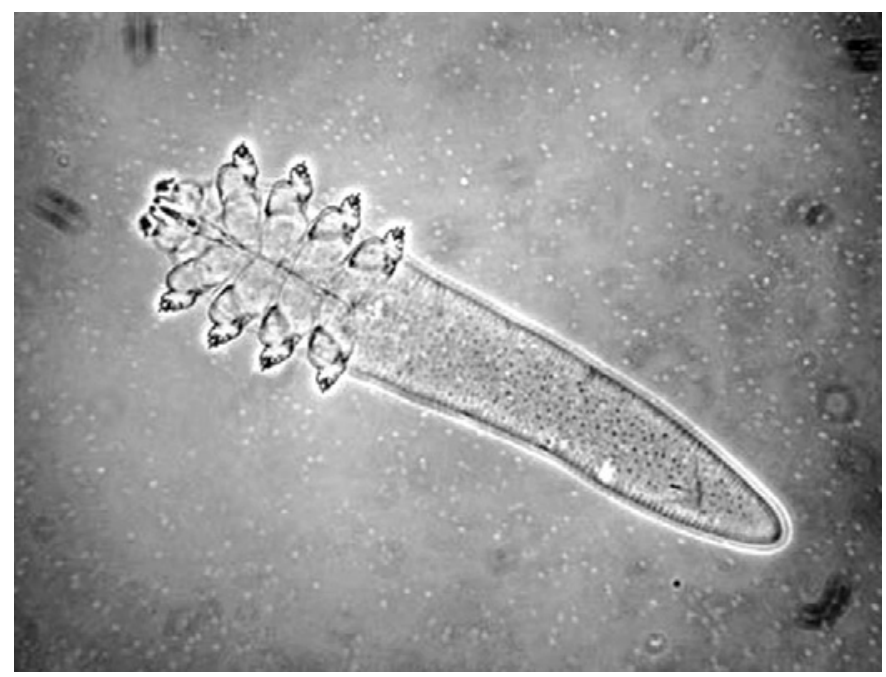

Figure 2. Demodex folliculorum under light microscope (X100 magnification). $(p=0.048)$. There was a tendency to find Demodex in aged patients. The mean age of positive and negative patients for Demodex were $58.2 \pm 1.8$ and $54.0 \pm 2.8$ years, respectively $(p=0.09)$.

In the control group, Demodex was more prevalent in females, but this difference was not statistically significant $(p=0.125)$. In the diabetic group, male gender emerged as protector risk factor $(p=0.048)$.

\section{DISCUSSION}

Blepharitis is a commonly progressive chronic illness considered one of the most found ocular disorders in clinical practice. The physiopathology is not entirely known and it represents a therapeutic and diagnostic challenge ${ }^{(12)}$. Different factors are involved in the pathogenesis of chronic blepharitis, including alteration of the ocular microflora, reaction to exotoxins, allergic response to antigens, changes in the dynamics of the tear film and dysfunction of the meibomian gland(12)

Demodex mites have also been associated with blepharitis and several pathological mechanisms have been suggested. The mites can cause a direct damage in the epithelial cell at the lash follicle ${ }^{(1)}$, induce a reactive hyperplasia and hyperkeratinization ${ }^{(13)}$ or mechanically block of the orifices of meibomian glands ${ }^{(14)}$. Bacteria were found inside and on the surface of Demodex mites. Some of them, such as staphylococci, produce exotoxins that can directly contribute to unspecific irritative symptoms or induce a host immune reaction ${ }^{(15)}$. In addition, proteins of the mites and their debris may also elicit a host delay hypersensivity reaction ${ }^{(13)}$.

The data about the prevalence of Demodex in diabetic patients are scarce. Akdeniz et al. found a significantly higher mean mite density and bigger mite mean size on cheeks biopsy of diabetic patients compared with a control group ${ }^{(3)}$. Clifford et al. analyzed the prevalence of Demodex on eyelashes of 256 subjects and also concluded that mites were more abundant in patients with diabetes ${ }^{(16)}$.

Various reports of Demodex infestation in association with acquired immunodeficiency syndrome and cancer chemotherapy $\mathrm{y}^{(9,10)}$ and the higher prevalence of Demodex in potential immunosuppressed subpopulations, such as pregnant ${ }^{(17)}$ and hemodialysis patients $^{(11)}$, have suggested that immunological deficiency may facilitate the overgrowth of the mites. Patients with diabetes have an increased risk for infections, but the exact mechanisms of the immunocompromised state are unclear.

Several abnormalities might contribute to the increased susceptibility and severity of infections in diabetic patients, including lower chemotactic activity of neutrophils ${ }^{(18)}$, reduced function of mastocytes ${ }^{(19)}$, poor leukocyte-endothelial cell interactions and decreased quantity of leukocytes in inflammatory lesions ${ }^{(20)}$, low oxidants compounds generation, a reduction in lymph node retention capacity ${ }^{(21)}$ and reduced release of cytokines, such as tumor necrosis factor alpha, interleukins and prostaglandins ${ }^{(22)}$.

In the present study we demonstrated that patients with active proliferative retinopathy showed higher prevalence of Demodex eyelashes infestation. The retinopathy is a severe microvascular diabetic complication that attack specially patients with long-term di-

Table 1. Prevalence of Demodex sp. in diabetic patients and a healthy control group matched by age and gender

\begin{tabular}{lccc}
\hline & $\begin{array}{c}\text { Diabetic patients } \\
\text { N (\%)* }\end{array}$ & $\begin{array}{c}\text { Control group } \\
\mathbf{N} \text { (\%)* }\end{array}$ & $\begin{array}{c}\text { Total } \\
\mathbf{N}(\%)\end{array}$ \\
\hline Demodex positve & $23(27.4 \%)$ & $16(19.0 \%)$ & $39(46.4 \%)$ \\
Demodex negative & $19(22.6 \%)$ & $26(31.0 \%)$ & $45(53.6 \%)$ \\
Total & $42(50.0 \%)$ & $42(50.0 \%)$ & $84(100.0 \%)$ \\
\hline
\end{tabular}

*= percentage of the total population of the study, including patients with diabetes and healthy voluntaries. $\mathrm{N}=84$. 
sease and poor glycemic control and that are expected to be in greater risk of immunosuppression.

Increased sebum production has been correlated with Demodex density ${ }^{(23)}$ and could be other speculative mechanism involved in diabetic patients. An experimental study showed cystic dilatations of hair follicles and altered lipid synthesis in the sebaceous glands of diabetic rats ${ }^{(24)}$. However this hypothesis is controversial, since others studies have demonstrated that patients and mice with diabetes tend to show a decreased sebaceous gland activity ${ }^{(25,26)}$.

Obviously, for ethic and cosmetic conditions, a generalized epilation of the eyelid is not advised. A simple random epilation may constitute a sampling bias. To improve the chance to detect Demodex, the eyelashes with cylindrical dandruff were preferred and fluorescein dye was used to improve the microscopic evaluation as previously described ${ }^{(27)}$.

Demodex infestation has a global distribution without race preference, but it is predominant in females and increases with advancing age ${ }^{(28)}$. Although the control group was composed by age- and gender-matched voluntaries, there was a tendency to find Demodex in aged patients and in the women. The blockage of the meibomian orifices by greasy eye makeup and hormonal alterations are possible factors involved in the higher prevalence in women.

\section{CONCLUSION}

Diabetes Mellitus showed to be a risk factor for Demodex folicullorum infestation of the eyelid, independently of gender and age. Further clarification of the role of Demodex in the physiopathology of blepharitis and the influence of metabolic disturbs are still required.

\section{REFERENCES}

1. Gao YY, Di Pascuale MA, Li W, Liu DT, Baradaran-Rafii A, Elizondo A, et al. High prevalence of Demodex in eyelashes with cylindrical dandruff. Invest Ophthalmol Vis Sci. 2005; 46(9):3089-94.

2. Lacey N, Kavanagh K, Tseng SC. Under the lash: Demodex mites in human diseases. Biochem (Lond). 2009;31(4):2-6.

3. Akdeniz S, Bahceci M, Tuzcu AK, Harman M, Alp S, Bahceci S. Is demodex folliculorum larger in diabetic patients? J Eur Acad Dermatol Venereol. 2002;16(5):539-41.

4. Erbagci Z, Erbagci I, Erkiliç S. High incidence of demodicidosis in eyelid basal cell carcinomas. Int J Dermatol. 2003;42(7):567-71.

5. Karincaoglu Y, Bayram N, Aycan O, Esrefoglu M. The clinical importance of Demodex folliculorum presenting with nonspecific facial signs and symptoms. J Dermatol. 2004; 31(8):618-26.

6. Türk M, Oztürk I, Sener AG, Küçükbay S, Afoar I, Maden A. Comparison of incidence of Demodex folliculorum on the eyelash follicule in normal people and blepharitis patients. Turkiye Parazitol Derg. 2007;31(4):296-7.
7. Divani S, Barpakis K, Kapsalas D. Chronic blepharitis caused by Demodex folliculorum mites. Cytopathology. 2009;20(5):343-4.

8. Kemal M, Sümer Z, Toker MI, Erdoðan H, Topalkara A, Akbulut M. The Prevalence of Demodex folliculorum in blepharitis patients and the normal population. Ophthalmic Epidemiol. 2005;12(4):287-90.

9. Nara T, Katoh N, Inoue K, Yamada M, Arizono N, Kishimoto S. Eosinophilic folliculitis with a Demodex folliculorum infestation successfully treated with ivermectin in a man infected with human immunodeficiency virus. Clin Exp Dermatol. 2009;34(8):e981-3

10. Damian D, Rogers M. Demodex infestation in a child with leukaemia: treatment with ivermectin and permethrin. Int J Dermatol. 2003:42(9):724-6.

11. Yagdiran Düzgün $\mathrm{O}$, Aytekin S. Comparison of Demodex folliculorum density in haemodialysis patients with a control group. J Eur Acad Dermatol Venereol. 2007;21 (4):480-3.

12. McCulley JP, Shine WE. Changing concepts in the diagnosis and management of blepharitis. Cornea. 2000;19(5):650-8

13. Bevins CL, Liu FT. Rosacea: skin innate immunity gone awry? Nat Med. 2007;13(8):904-6 Comment on Nat Med. 2007;13(8):975-80.

14. Gao YY, Di Pascuale MA, Elizondo A, Tseng SC. Clinical treatment of ocular demodecosis by lid scrub with tea tree oil. Cornea. 2007;26(2):136-43.

15. Wolf R, Ophir J, Avigad J, Lengy J, Krakowski A. The hair follicle mites (Demodex spp.). Could they be vectors of pathogenic microorganisms? Acta Derm Venereol. 1988;68(6):535-7.

16. Clifford CW, Fulk GW. Association of diabetes, lash loss, and Staphylococcus aureus with Infestation of eyelids by Demodex folliculorum (Acari: Demodicidae). J Med Entomol. 1990;27(4):467-70

17. Aydingöz IE, Dervent B, Güney O. Demodex folliculorum in pregnancy. Int J Dermatol. 2000;39(10):743-5

18. Mowat A, Baum J. Chemotaxis of polymorphonuclear leukocytes from patients with diabetes mellitus. N Engl J Med. 1971;284(12):621-7.

19. Bagdade JD, Nielson KL, Bulger RJ. Reversible abnormalities in phagocytic function in poorly controlled diabetic patients. Am J Med Sci. 1972;263(6):451-6.

20. Sannomiya P, Oliveira MA, Fortes ZB. Aminoguanidine and the prevention of leukocyte dysfunction in diabetes mellitus: a direct vital microscopic study. Br J Pharmacol. 1997; 122(5):894-8.

21. Moriguchi P, Sannomiya P, Lara PF, Oliveira-Filho RM, Greco KV, Sudo-Hayashi LS Lymphatic system changes in diabetes mellitus: role of insulin and hyperglycemia. Diabetes Metab Res Rev. 2005;21(2):150-7.

22. Alba-Loureiro TC, Martins EF, Landgraf RG, Jancar S, Curi R, Sannomiya P. Role of insulin on PGE2 generation during LPS-induced lung inflammation in rats. Life Sci. 2006;78(6): $578-85$.

23. Diaz-Perez JL. Demodex mites in rosacea. J Am Acad Dermatol. 1994;30(5 Pt 1):812-3 Comment on J Am Acad Dermatol. 1993;28(3):443-8.

24. Cakmak S, Gül U, Gönül M, Demiriz M, Cakmak A. Statin therapy and diabetic skin. Adv Ther. 2008;25(1):17-22

25. Seirafi H, Farsinejad K, Firooz A, Davoudi SM, Robati RM, Hoseini MS, et al. Biophysical characteristics of skin in diabetes: a controlled study. J Eur Acad Dermatol Venereol. 2009;23(2):146-9.

26. Sakai S, Kikuchi K, Satoh J, Tagami H, Inoue S. Functional properties of the stratum corneum in patients with diabetes mellitus: similarities to senile xerosis. Br J Dermatol. 2005;153(2):319-23.

27. Kheirkhah A, Blanco G, Casas V, Tseng SC. Fluorescein dye improves microscopic evaluation and counting of demodex in blepharitis with cylindrical dandruff. Cornea. 2007;26(6):697-700.

28. Sengbusch HG, Hauswirth JW. Prevalence of hair follicle mites, Demodex folliculorum and d. brevis (Acari: Demodicidae), in a selected human population in western New York, USA J Med Entomol. 1986;23(4):384-8. 